\title{
Towards an authentic transformation of the Church of Christ in Zimbabwe
}

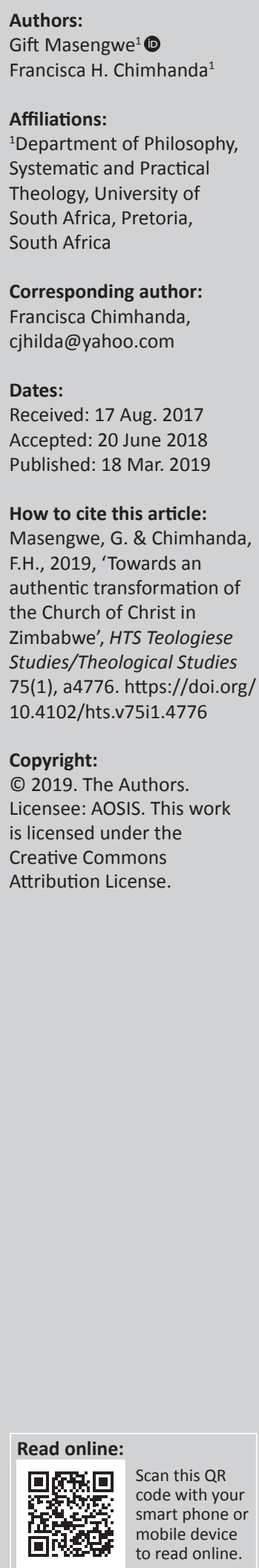

This article evaluates the impact of transformation in the Church of Christ in Zimbabwe (COCZ) over the past 10 years. The study is guided by the following questions: What does it mean to be COCZ in the Zimbabwean society? What is the COCZ mission that empowers it to play a meaningful role in nation building? The critical analysis is observed from the Christian education (CE) pedagogy. This raises questions on the historical foundations, transformation tenets and future plans and guidelines towards authentic transformation. Transformation could be affected by new developments, and thus participants need to be guided accordingly. The article gives a critical analysis of the COCZ journey experiences using a dialogical approach to $\mathrm{CE}$. This study presupposes that lack of $\mathrm{CE}$ is a limiting factor to the transformation process in the church. This study is an interdisciplinary study that combines missiology, African ecclesiology and Christian theology. The study was conducted using surveys, observations and interviews among leaders and members of the COCZ.

\section{Introduction}

Most evangelical churches went through challenges at the onset of the third millennium. The Church of Christ in Zimbabwe (COCZ) reportedly underwent tension and crisis with Pentecostalism at the end of the first decade of the third millennium in the Christian landscape in Zimbabwe because of social and religious changes. The church faced challenges with the first wave of Pentecostalism, losing members to the Zimbabwe Assemblies of God Africa, started by Apostle and Archbishop Dr. Ezekiel Guti, and the Apostolic Faith Mission in Zimbabwe, and not to neo-Pentecostalism, which fetched most of its members from huge Pentecostal churches. To retain members, pastors in the COCZ innovated with corporate praying, speaking in tongues, spirit praying and prophecy. These innovations were meant to challenge traditional norms, and thus pastors held meetings over the perceived changes. Meetings became platforms for justifications and counter-justifications to defend actions or doctrinal positions. A few pastors indicated their awareness of the times of change (globalisation and liberalism) rather than lack of doctrinal integrity. Generation gaps led to conflict between older and younger pastors, and thus the third millennium challenged the COCZ's theology and polity. The COCZ is a colonialmissionary church whose theology and epistemology faced postmodernist challenges, and in this process its parameters for change could guarantee its effectiveness and relevance in the postmodernist society. COCZ is a mainline denomination that was started at the onset of colonialism and is affiliated with the Zimbabwe Council of Churches (ZCC). The church has several mission schools, hospitals and orphanages throughout the country for service to communities. The church has struggled to keep up with the changing times, and this article proposes to develop a pedagogical approach that remains faithful to the COCZ founding principles and its relevance to the changing society.

\section{Background to the study}

The COCZ originated with the coming of missionaries from New Zealand in the later 1890s. The colonial era became favourable for the COCZ to grow and open mission centres throughout the country, such that by 1980 the church had one of the largest numbers of mission centres in the country. After independence, the COCZ continued to engage in a number of projects. At the beginning of the new millennium, it first resolved to build a conference centre (CC) and a boarding school at its newly acquired land in Somabhula, Lower Gweru. It also proposed to build a new church constitution upon which its projects like the CC were going to be hinged. Like the Israelite nation coming out of Egypt, it began on a journey of making a constitution for itself and also building a $\mathrm{CC}$ for the denomination. At the end of the constitution making process, the chairperson of the committee, Judge Justice Joseph Mafusire, stated in his report, 'The journey to this occasion started at Somabhula itself on 16 February 2013' (Mafusire 2015:1). The constitution adoption 
marked an occasion of social, economic and political transformation that was of greater significance to the church's renewal process than any event since the days of the missionary leaders. Some middle-aged people who had been members of the church since their teenage years confessed that 'this was a historic moment' and a 'period of renewal'.

In the postmodernist era, church splintering has challenged the Christian fraternity. To give the church a new lease on life and to pursue unity, it was believed, the COCZ needed a unifying element in the form of a national church constitution. The church had no known code for rules and regulations, although elderly members reported that they had a constitution crafted in 1972 that did not make it into the hands of the younger generations.

Unfortunately, missionaries displayed discomfort at pastors taking key leadership roles ahead of church elders, as was the tradition of the American Churches of Christ (Altman 2014). The thinking contrasts with the world system, where top leadership positions are reserved for experts in their fields of study. Missionary thinking fomented rather than resolved an existing conflict between pastors and elders in the church (Mafohla 2017). Many church members were surprised that those who trained pastors had no confidence in their own products and thus were comfortable in placing pastors under persons who had received secular education to run sacred institutions. In two contrasting presentations at COCZ conventions and conferences, Mr Altman (2014) and Mr Hart (2016) did not agree on how the unique character of the COCZ was going to be protected, to maintain especially the Restoration Movement (RM) theology of unity and ecumenicity in the Christian community. The researcher attended both conference presentations and personally experienced the recitation of the RM ideals in both meetings. The earlier one was more of a doctrinal talk show devoid of RM content, which barely differed from previous local doctrinal talk shows by dissenters, also nicknamed 'African black missionaries'. The euphoria was not to live forever; as a part of the church constitution making process (CMP), the church's lack of internal transformation was put to the test, and thus this article examines the tenets accompanying the transformation process (TP).

This article looks at the COCZ journey to provide a case study of the experiences of the Zimbabwean church TP between 2000 and 2017 and to propose tentative insights into its journey into the future. This reflection is informed by the basic tenets of a transformed faith that seeks to transform the world. This article is partly the telling of one person's journey and personal struggles towards being part of the COCZ family. The church endeavours to be relevant to postmodernist Zimbabwean society as well as remaining faithful to the heritage and ideals of the RM. Thus, this article faces the challenge of objectivity although it retains credibility and criticality to indigenous ecclesiology. This action research study (Carr \& Kemmis 1991) was done using social science research methods such as content reviews, observations and 15 informal interviews (Bless \& Hugson-Smith 1995), in order to intervene in the unfolding developments in the history of the COCZ (Rothman \& Thomas 1994). The article looks at the history of transformation by locating this history in its proper context. Secondly, it looks at the transformation tenets of the COCZ based on the vision of building a moral and informed Zimbabwean society that was given by Rev. Edwin Magwidi, the COCZ president, concerning church mission and ministry. Thirdly, the article evaluates the educational approach to the transformation in the COCZ today. This is because the study is a reflection of the historical events in the transformation journey of the COCZ, and some interviews were carried out to aid this reflection where Paulo Freire's dialogical pedagogy was used to allow church members to think and act independently, without compulsion, in the church's TP (Freire 1976; 1985; 1986; 1989). This concept applies to the COCZ TP as it allows members to reflect on their words and actions in transforming the COCZ for postmodern society.

However, for the success of the TP, Pastor Tawanda Sibanda of Windsor Park Church of Christ, in his study on church administration through the ZCC Ecumenical Centre, wrote a study of the COCZ's need for an administrative national structure in which ministries and the structure of the church were going to operate. In the next section, the developments are discussed.

\section{The structure and ministries of the Church of Christ in Zimbabwe}

The COCZ is a missionary church that emphasises the dominance of the local congregation on mission and ministry in the church. However, in the 2014 national church constitution, new structures and changes to the old model of autonomy increased accountability by vesting power in the highest decision-making body, the National Church Council (NCC). The NCC is composed of the National Executive Committee (NEC) and representatives of fellowship bodies and local churches. Local churches are organised into districts, wherein the district elects a committee that represents local churches, whose chairperson, secretary and two representatives, one from the elders and one from the deacons, are members of the NCC. The NCC, through the national constitution, is required to set up committees for evangelism, discipleship, education, health, and counselling among others. Christian education (CE), unfortunately, is the responsibility of the pastor's fraternity and is not clearly part of any of the NCC committees. Although pastors lead in many ministries, unfortunately the NCC does not allocate resources for CE. Thus, most of the church's work is done through fellowships and elected national committees, without which no work can be done as the COCZ has no full-time national secretariat. The new structure developed because the Zimbabwean context demanded self-sustenance, selffinancing and self-definition as the COCZ's context differed from that of the US. The COCZ adopted an Afrocentric approach to leadership, church structure, laity responsibility, discipleship and church autonomy. With the constitution, the COCZ produced a moratorium on the foreign relations with 
missionaries in how it determined its own transformation (Sibanda, 2016; COCZ Constitution, 2015).

\section{Locating the transformation journey}

In 2011, in Masvingo, for the 2010 conference review, the council elected a new committee that was tasked to embark on the vision of the church to create a CC and to build up the church's constitution. One elderly pastor, Pastor Enock Jirrie (2011), immediately remarked in the meeting:

'We are entering into a phase of the leadership of the Holy Spirit. If Jesus was here he would tell us what he similarly told Peter at the confession, 'not by your moral intelligence are you moving with the spiritual call but the quickening of the spirit of God.'

When the committee that had run the conference for the past six years left, they thought the new committee was not going to succeed on the charted new course. The outgoing committee had refused to yield to the people's calls for a CC, but on failing to stand their ground upon the people's calls and demands, they gave away their offices to a new and vibrant committee of relatively younger members thinking that dissenters (predominantly the black elite receiving foreign funding for church work) were going to place hurdles from outside of the committee. Shockingly, the new crop of leaders skirted their way through the hurdles and the CC project gained momentum, forcing the former NEC members to make a dramatic change of direction by buying into the project. The NEC then set up a land committee to oversee the issue of the CC project. The land committee identified pieces of land that were offered by the church's regions. The CC land identification committee saw Lancashire, which had been offered to Hippo Valley Christian Mission through One Mile Trust. The Lancashire Farm in Gutu, one of the farms that had been taken during the fast-track land reform programme, had lain idle for a decade. Several pieces of land were evaluated, including Manyotshwa in Beatrice, which had recently been given to the Harare Region COCZ to build a school and a regional worship centre. The land that was favourably recommended by the land committee, unfortunately, was a piece of land in Gweru at Somabhula, which was similar in size to the one in Gutu. While the conditions were similar, Somabhula had been given to the Gweru churches to build their regional CC while Lancashire had been given to an individual ministry and had land costs attached to its ownership. At that time, Pastor Fanny Nyamutora, who was classified as conservative, was the national conference president. In 2012, he shocked the former NEC members by pushing for the adoption of Somabhula as the church's CC project. He also expressed the need to immediately build up the church's national constitution. Emerging theologians and academics in the COCZ became excited to participate in the process, as some had long clamoured for the transformation of the church along postmodernist patterns (De Gruchy 2005:206).

Further, the clergy and lay leadership in both congregations and regional committees were caught unaware of the need to educate the church on the path it was taking and to prepare it to encounter detours and hazards because of this sudden change. The church was moving from naivety, in which it had lived for too long, to reality, in which there were no certainties. The church then went into the challenges of finding the way forward and a theology for unity and ministry in the CC construction and CMP debates as reality slowly took shape and persons not thought of previously as taking up leadership began taking over. As a result, naivety gave rise to reality, and the former leaders of the same system started challenging the processes, products and personalities to interfere with the TP. African leaders, herein African black missionaries (AMs), who were handpicked by missionaries to take over mission work when government refused to renew permits for foreign nationals, became very unhappy, yet during their terms of office, as they had previously been removed from the national leadership, had failed to develop a theology for their successors as well as a succession plan through a thoughtful religious and theological renewal and creative option for transformation in the church. Pastor F. Mate (2016) of Collen-Brander Church of Christ (CCOC) at a CCOC meeting on 05 May 2016 to confirm the new direction the national church was taking stated:

'The COCZ today has complex options. On one hand it has mission and ministry to accomplish; while on the other hand it has unity and doctrine to uphold. To be able to do both, we need to move with the times without leaving our brothers and sisters behind.'

Also, Pastor E. Magwidi (2015), the 2016-2019 president of the COCZ's NEC and the NCC, speaking at the August 2015 conference at Somabhula, stated in his final remarks that:

'The COCZ needs to prepare itself for a great harvest in the country due to the rapid changes and the needs for the church to guide in nation-building; and to see to it that we send ministers, evangelists and missionaries into every part of God's harvest field in the country and even beyond Zimbabwe, and abroad, in other African nations and even other continents.'

The words of the COCZ president echoed similar circumstances urged by Walshe (1995:138) to the Methodist Church in South Africa (MCSA) to mediate in the country's political issues and to provide space for love, mercy and justice. In the face of sudden social changes, these words never had any meaning in the ears of theologians and academics in the COCZ until the church experienced increased resistance in its own ranks, beginning with resistance to the work of the CMP, where a volunteer to the committee made retrogressive remarks and in the process reproduced his own copy of what he termed the constitution his constituency was going to accept. He finally resigned from the CMP committee and mobilised people to resist a constitution to which he had personally contributed $80 \%$ of the material. Some participants reflected on the resistance whether it was coming from God or was driven by motivations of self-interest - and decided to wait until time would tell. Moreover, meetings by heads of private ministries that took over church properties at the return of COCZ missionaries to their sending communities condemned the process and made joint written submissions condemning the 
content and process of the CMP. This resistance led to a counter group within the church composed of those who considered themselves as the midwives of the TP of the COCZ and self-interested pharaohs who were determined to see an abortion of the TP, or its death in infancy. Dissenters tried to undermine the TP by refusing to reconcile with the incumbent leadership. Looking at what a transformed church would do, transformation appeared to be a necessary process for the church. De Gruchy (2003:452) asserts that in a transforming society, the church needs to follow suit in order to maintain its role of ministry and service to the community. This meant that the COCZ needed to meaningfully transform in order to minister effectively to a transforming Zimbabwean society, as declared in the conclusion of the 2011 men's conference at Matopos, themed 'Church at the Crossroads': 'We are prepared to transform the COCZ founding ideals in order to prepare ourselves for effective mission and ministry to the fast changing postmodernist subcontinent of Africa'. The declaration led to various written and verbal theological responses by attendants such as the infamous letter by Dr Mazambara (Great Zimbabwe University) that castigated proposals to change the leadership structures and rules governing the church. Commenting on the MCSA, VillaVicencio (1992) supported the idea of church transformation to move with the demands of the changing times. In addition, Oliver in The Next Step (1995:1) stated that the MCSA needed to transform to meet the new demands of a changing society.

As contesting groups in the COCZ did not make any efforts to unite, the ministry of the church continued to face challenges of unity in Christian witness. This contrasted with the calling of the church in the world, where it is seen as the conscience of society and hence a leader in healing and reconciliation processes, yet it is itself irreconcilable (Dombo 2014; Manyonganise 2016; Masengwe 2010). It is worthy to note that all key dissenters in the CC project had been, in one way or the other, leaders of the COCZ. If the dissenting voices had acted fairly for the sake of unity and ministry of the church, the COCZ would have adopted a resolution to educate the church after providing study guides for the purpose of assisting COCZ congregations on this journey. The COCZ was not only affected by the journey but also by finding ways to appropriate itself on the journey because of the changes in society.

\section{Journeying to transform a movement into a church}

The journey began with a constitutional referendum, which ushered the COCZ into a fully-fledged religious institution on 19 September 2015. The road to the referendum was sloppy and nasty, as some groups tried to buy time, expecting they were going to change the leadership of the conference before the constitution was accepted, or soon after its acceptance, so that the document could be undermined or destroyed. On the referendum date, the dissenters hired buses in an attempt to rig the elections. The CMP committee came up with a vote per committee system, which outlawed all the ordinary members who had been bussed to the referendum centre on the day. The process began with a presidential address on what the church was entering into and the role the church was assuming in the family of other organised churches in the country. Previously the church used to gather for fellowship, education and communion celebration with little reflection on the purpose and mission of the church in the world. The NEC president highlighted that, having a constitution, the COCZ was setting the stage to visibly participate in evangelism, discipleship and ministry in the country. The church's NCC was going to allow all people to participate in the church activities through their regional representatives, and in turn the NCC was going to make convocations on new projects and programmes as mandated by regional representatives. The COCZ was being set on a journey into a new era of ministry, mission and service to the nation. The sudden departure of white missionaries from the national church leadership had created a vacuum and disorientation that demanded the new crop of Christians to engage in the CMP so as to organise themselves and indigenise the church. This promised to preserve the important functions of the church to society the same way missionaries positively impacted the Zimbabwean nation in education and health during and after the colonial era, especially the infamous 'Grace Todd's African Primary Education System' (Chigwedere 2002; Paul \& Grundy 2011:631). Thus, 'The Southern Rhodesian African Education system was the product of one person' (Storey 1994:2).

President E. Magwidi's speech at the constitutional referendum on 19 September 2015 gave the vision statement for the NCC convocation (assembly), which was to 'be participatory, and dialogical' (Theilen 2002:70). He stated that the COCZ was:

'entering a period when every member of the church is to participate in this shared process of listening to the voice of God and to discern His guidance, so that we can find each other, and together, we owe it to our responsibility for becoming an authentic church in the shaping of the future of Zimbabwean generations and in this, we are shaping a future Zimbabwean society.' (Magwidi, 19 September 2015)

He further emphasised:

'Our vision is the full participation of every COCZ member in their devotion and worship of God at this centre by allowing you to participate financially by paying a dollar development fee for the centre every month, and to follow upon how your participation is impacting the centre as well as suggest what you want to see built, planted or removed from this centre to enhance your use of the place as God gives each one of us a vision to do so. So as we take the constitution today, if we agree, we are all participating in support of this work in every way possible. I want to encourage you to listen to the voice of God and not the advices of men [sic], for men [sic] will change but God will not disown His word. I therefore want to welcome all people who have always been here and those who came for the first time, to participate in shaping the future of the COCZ.' (Magwidi, 19 September 2015)

The initial date for the referendum was 11 July 2015, but it was postponed until 19 September 2015 because some were 
saying they wanted to revise the constitution before they accepted or declined it. The executive made all necessary arrangements to accommodate the referendum dissenters, and to make the process free and fair for all. Dissenters could not rig the elections because there was no room, and they departed before the process was carried out. Fortunately they all had the opportunity to hear from the president, and most of the people who were hired voiced dissatisfaction with the actions of the leaders of the dissenting group. The committee was also criticised for pushing a strategy that did not consult the dissenting party. Thus, dissenters accused the executive of providing the answers so that people would ask the questions. The accusation was denied by the president, who related his speech to Storey's (1994:2) statement that elitists practice a top-down approach but good leaders listen to the people. Thus, the president finally stated in his response:

'We have learned from the past that our church has been using elitist decision making, and by blocking it, we are putting in a grassroots-based planning approach, especially when the NCC representing the people writes down the agenda for the COCZ journey after the 2016 national conference.' (Magwidi, 19 September 2015)

Since the time of the referendum many things have happened in the COCZ, which the NCC created as an opportunity for people to give their input. In the rank and file of the church, people have begun to ask relevant questions like: 'What is it that God is calling us in the COCZ to, and what are our priorities?' Because of the mooted plan to split the church, many ordinary people who never saw the threat of the existing impasse began to assert the need for the NCC assembly in decision-making. The process seems to have been consultative and dialogical in forging a way forward for the COCZ, because it became based on a committee system. This move mobilised many members of the COCZ to participate in the journey. Members were further mobilised in a verbal presidential message, a vision of the journey after the August 2016 national conference:

\footnotetext{
'God is calling all of us to participate in the experience of the Holy Spirit, the God who renews us inwardly, and is going to send all of us out into God's mission field to seek and to serve the lost. As a church, we are listening to the hopes and fears of the ordinary citizens of our country, and we have the experience of the transforming power of the resurrected and glorified Christ, which releases us from men-made [sic] religious machinations and enables us to celebrate with people in all their rich variety. Here we have covenanted with one another to be true instruments of God's transforming experience. Please 'go ye therefore into the entire world and become my disciples' (Matt. 28:18-20), and 'whatever ye have heard me in secret, proclaim at the rooftops and mountaintops'; and be the salt that will forever change the structures of our society with the Gospel of Christ.' (Magwidi, 24 August 2016)
}

From these remarks and outgoing discussions, themes emerged, and this study attempts to make a reflection on them, namely, a closer walk with God, a revitalised vision for mission work, member mobilisation for ministry, unity through diversity and sensitivity to existential needs, which freed pastors and lay leaders to their vocations (Theilen 2002:70). Thus, with the journey story in the COCZ, the process aimed at rebranding and reinvigorating a tired and stagnant church to regain its former vibrancy and to engage into its own transformation in preparation to serve transforming Zimbabwean communities.

\section{Tenets towards the transformation process}

For the COCZ to succeed in its transformation, a number of observations are useful, such as the reinvention of the COCZ systems (Theilen 2002:70). It has to observe four dimensions of transformation, namely religious, intellectual, moral and political. Mwambazambi and Banza (2014b) state that:

[t]he spiritual, intellectual, moral and socio-political dimensions of the transformation can be catered for so that the complete inner being of humans, as well as their social and political attitudes and behaviours, can equally be transformed to maximum spiritual, personal and socio-political profitability. (p. 1)

Firstly, the COCZ is called to observe the tenet of a deep spiritual walk with God as a denomination. Citing Adeyemo (2006:1303), Mwambazambi and Banza (2014b:9) argue 'that African Christians seriously lack spiritual depth because of poor Christian education (CE) and adaptation' to have a deep spiritual walk with God. This can be achieved through rediscovering its past heritage in the founding ideals of the $\mathrm{RM}$, namely, the essentiality of the Bible, the centrality of Christ and the guidance of the Holy Spirit on scriptural study, prayer, worship, fellowship, CE and meditation. It needs to be clear that the study of the Bible and Christian spiritual exercises must be done in view of a movement that is transforming into a fully African church. The COCZ's NCC is obligated to reconsider its commitment to a deep spiritual walk with God by establishing a review centre for the production of religious and spiritual materials. Thus, the COCZ needs to develop a department to oversee religious devotions and reflections to aid in the COCZ transformation journey. The materials must give biblical supports and theology on how God is transforming the COCZ to be able to minister in modern Zimbabwean society today.

Secondly, the COCZ needs to focus on a revitalised vision for mission work. In the COCZ, debates have focused on mission centres and people have salivated for their control because from them they gained some level of dignity and importance as well as the pride of the COCZ heritage. In recent times, control of the institutions has been associated with financial and economic benefits. In this tenet, the COCZ should be called to invest in its mission goals and vision for evangelism, discipleship and ministry. To this effect, narrowing the church's focus onto the mission centres hindered the church's mission and service to the world and ministry to its members. This has been blamed for the decline in the COCZ membership and the rampant multiple religious consciousnesses (Masengwe, Machingura \& Magwidi 2012), as well as fearful leadership in the church (Bhebhe 2016). The COCZ president has fortunately, in a number of his addresses, always called 
for the church to be mission-minded and history-makers instead of being backward-looking, history-talkers. This realisation is not new, for John Mark Pemberton retorted the need for indigenisation in the COCZ in his missionary reports. Unfortunately, no one has talked about transformational leadership to carry out the mission work as lack of relevant leaders is causing lack of success in the church (Mwambazambi \& Banza 2014a:1-9). To this effect, the COCZ evangelism team needs to be boosted and given new mandates, among others, to do mission work as guided by the teaching of the Bible, the ideals of the RM and the COCZ code of belief as enshrined in its national constitution.

Thirdly, the COCZ needs to focus on member mobilisation for ministry. The idea of having many members is to root the faith into the lives of many Africans. For this reason Tinyiko Maluleke (1997:210), quoting Bediako (1992), says:

$[t]$ o the extent that African theology attempts at rehabilitating Africa's rich cultural heritage and religious consciousness has [sic] been made as a self-consciously Christian theological effort, it [sic] can be said to have been an endeavour to demonstrate the true character of African Christian identity. (p. 3)

The COCZ needs to reinforce the work of both pastors and the laity because the Bible teaches about the 'priesthood of all believers'. This identity of the church here is defined by the theological identity the church develops. In this way, pastors failed to play the role of shepherds of the flock, and elders to model leadership principles to members. Fellowship committees are a symbolic feature of the tenet, and members need to make a meaningful contribution to church. This calls the church to take seriously ministry for various members in the church such as single women, university graduates and young professionals, widows and widowers among others, for this increases representation among concerned groups in NCC meetings. This, it is hoped, reduces elite-ordinary member ratios and indigenises the church and its theology. Member mobilisation strategy enables all members to participate in decision-making at all levels of the church rather than leaving the church because, in the COCZ, all are ministers one to the other. This enables every member in fellowship, and representation in the NCC decision-making parallels every member's work to that of pastors and elders of every nature in the church. The COCZ missionaries from the USA mainly favoured the neo-Pentecostal model of personal ownership and privatisation of church entities, while the Africans are driving for a communal form of ownership, leadership and decision-making that allows all professed members to be part and parcel of the life of the church

Fourthly, the COCZ needs to focus on unity through diversity and sensitivity to others' existential needs.

Divisions in the COCZ are rumoured to have been initiated by divisive payment systems for church ministers and leaders in the church. Progressive organisations have managed to unite their fronts through 'constructive engagements and critical solidarity, despite its internal divisions which may raise questions about its integrity' (Duncan 2002:333). Thus, the COCZ pastor's fraternity made a declaration to remain united without assessing how finances and economic prospects would render the church divided. A former member of one Harare church stated that it was marvellous attending at their church because their pastor ran a trust fund that received financial support from the US, which made things happen without the members' efforts. This scenario contrasts with other scenarios in the region, especially zones that raise money to pay for rentals and the pastor. So there are churches with members accessing funds from the USA and New Zealand, and they are predominantly viable, while the majority of the churches are characterised by lack and struggles. Leaders for this kind of organisation have to be multifaceted to accommodate those who have and those who lack (Duncan 2002:340). On the basis of this lack, the kind of ministerial staff attracted to such churches, especially rural churches, are people who may not find ministry work in the city churches. In this article, the call to unity needs to begin by considering financial resources as well as issues of the marginalised, especially women ministers (Machingura \& Nyakuwa 2015). The COCZ needs to understand the effects of gender affirmations in the society and in the church and to appropriate them for viability in the church. The appointment of a female pastor for the Children's Church at HCC and another at the Chiredzi Children's Village are milestones to be applauded in the COCZ, although more needs to be done. Diversity and sensitivity call for African leaders to identify with the local resources and challenges in order to bring a new morality and social transformation through how the church lives in the world (Duncan 2002:333-342).

Fifthly, the COCZ needs to focus on servant leadership. Servant leadership is also evaluated with the ubuntu philosophy because of the values involved (Meylahn \& Musiyambiri 2017:1-6). At the Anglican Church in Harare, the leaders of the church merged church practices and Christian experiences with worldly practices, resulting in boundary-transcending goals of human experience and expectation. From the experiences of the outgoing events in the COCZ, many people have voiced that dissenters bend towards being a self-serving community of individuals in their decisions and actions. People complained that all leaders were authoritarian and compulsive. Authoritarianism is a leadership style that is viewed as 'not consistent with the teaching of Jesus' (Theilen 2002:73); thus, transforming the church was a desire to have a renewed leadership for the rising Zimbabwean form of religious nationalism, which was going to affect how the church was going to participate in the national discourse. Participation of the church at a higher level demanded that the church understand itself and be able to run its own affairs well. In the postmillennial TP, the COCZ sought to renew and change its own structures, hierarchies and authorities to set up professional boards to run schools, among others. Church members became encouraged to participate in a church that was ready to give the denomination back to God to run it for the good of the members. This therefore called for democratisation in the church at all levels, and this was voiced as the most contested 
point by dissenters, who felt that increased power and involvement of fellowships disempowered them. So dissenters reacted by threatening to break away to retain their power, away from a transforming church that was going to affect their privileges. This is similar to what Robert Matikiti (2014) researched to find out whether violence in the church today is a result of violence in the early church, as Christians then refused to engage in military activities. In the new constitution and NCC, fellowships have the right to appoint everyone from NEC to mission centre boards.

Finally, the COCZ needs to focus on freeing pastors and lay leaders to their vocations. This idea is premised on refocusing pastoral vocation and lay primary responsibilities (Oliver 1995). Today, elders and deacons interfere with the work of ministers, especially in congregations where the laity did everything before the church appointed a full-time pastor. This also requires laity to be clearly assigned responsibilities in their areas of expertise. At one church the research team attended, the pastor was responsible for administration, disciplinary matters and pastoral responsibilities and the elders supervised his work. What the pastor did not like to do was least attended to because $20 \%$ of the members (church board) supervised the work of an individual. The laity, however, should be encouraged to imitate what they think can bring vibrancy and diversity into the church from their fields in law, medicine and health, education, agriculture and social sciences. This call thus frees everyone, minister and laity, from engaging in useless things to do what is enshrined in their primary callings and vocations. To this effect, the national leadership will do a favour to the church by teaching against bureaucracy and elitism, where leaders push pieces of their agenda around and spend the rest of their lives in private meetings and fail to fulfil their primary vocations. While dissenters are threatened by most of those tenets, this part challenged them to take their responsibilities seriously and to do what they can do best, rather than concentrate on a seeming power struggle to allow ministers to be ministers for the church and elders, elders for the flock. In an interview in Harare, one elder bemoaned:

'When is our minister going to be in ministry for us? We desire to be visited by him at our point of need, in our homes, places of work or leisure moments. Most of the times I want to see him, I visit him in his office, but the secretary always tells me that he is in a regional meeting or disciplinary hearing. I wonder whether he is the only capable minister to deal with such issues in a region with more than 30 pastors.' (fifty-year old male, elder and businessman in telecommunications)

In all, however, these tenets are not without challenges of their own - for example, financing - and they need to be approached with care, without which the journey of the COCZ to faithful transformation may die a natural death. In fact the idea of a breakaway in the church is premised on the desire to renew and reinvigorate the church for mission in a transforming society, without losing privileges - thus without proper plans, guidelines and thinking but on security of one's existential concerns. From here, the study turns to criticising the COCZ weaknesses in this journey.

\section{Towards a transformed Church of Christ in Zimbabwe}

The tenets endeavour to make us understand the COCZ differently, and here we need to hear the voices of those participating in the journey. By listening, leaders need to enter into a dialogue with their people's voices. Dialogue is a process of mutual talking and learning; and the Brazilian Paulo Freire's dialogical pedagogy emphasises dialogue for genuine transformation. Paulo Freire teaches about dialoguing from oppression to freedom and liberation (Freire 1976). For one to be liberated, there is need for constant dialogue between the oppressed (here, converts and pastors) and the oppressor (herein, elitists), faith and culture, freedom and education, among others (Freire 1976). Through dialogue, 'humans meet to reflect on reality, as they make and remake it' (Freire \& Shor 1987:74). From Freire, there is need for leaders to dialogue with followers; as teachers are to learners in a dialogue to format the education curriculum, so should church leaders be to converts in interrogating the church's theology and CE programme. Unfortunately, dissenters in the COCZ have used the 'banking system of education' (Freire 1976:54; Westerhoff 1976:47), which interfered with the building of a new Christian community for the COCZ. No truer words than those of Parker Palmer (2001) can be emphasised in the COCZ's TP:

Learning in the context of Christian life involves the process by which people are introduced to the Christian community; its stories, people, ways and vision of the world and incorporated into that community, experiencing its fellowship, participating in its mission, and moved by its passion. (p. 90)

This study proposes that the COCZ's journey of transformation is being confronted by a number of challenges, and to effectively address those challenges the church needs to seriously seek clarity on its systems of CE. Theologians and academics in the church need to clarify how the church's educational strategy can be introduced and implemented. The process has to be done at the behest of all people, and ownership of the programme must begin with appreciation of the need for doctrinal clarity, agenda setting, skills alignment, the timing of God and deep theological reflection. Without clarity in a number of these issues, church debates tend to evoke responses motivated by tendencies of selfishness on the part of the general membership, clergy and laity, as they emphasise what is comfortable to themselves and their activities. In all, the COCZ leaders need to note that their church cannot be transformed by individuals, but must rather transform itself from within even though leaders embarked or did not embark on the CC project and the CMP. This leads to the thesis that $\mathrm{CE}$ has to be seriously taken up, during this time of labour pains, to help the COCZ deliver a renewed form of itself without possibilities of a religious stillbirth or infant murder. The following section outlines what the COCZ needs to pay attention to and where intentional CE must be done to succeed in its TP. 


\section{An exhortation to the Church of Christ in Zimbabwe intentional Christian education plan(s) of action}

In this section, the study implores actions the church must consider in its intentional CE programmes. Firstly, the COCZ needs to clarify its shared goals in order to empower the church on its mission and vision of effectively ministering to the transforming Zimbabwean society. The leaders can ensure all are supportive of this thinking. In addition, followers need to be catechised into the journey goals without selectively emphasising only those elements that appeal to the individuals' appetites. This also demands transformation of practical and philosophical structures in the church and the equipping of all COCZ members to be goal-oriented, effective implementers of the vision. The process need not be viewed as the leadership strategy to mobilise a critical mass of support only to remove the obstacles standing in their way to total power and control, rather than allowing people, in their totality, to do their part of the mission work. If, on the other hand, the leaders stopped the COCZ from undergoing the process of transformation, the membership might be critical of the leadership, which initiated a process perceived as good governance in the household of God but in imitation of the world's democracy. Thus, transformation repositions the leadership of the church in Zimbabwe, to ensure how the vision of the church affects grassroots members and communities. The COCZ can depart from the system of just giving people charity, to real advocacy, prophetic ministry and knowledge of real issues for people at the grassroots level; for example, the practice of unity at both the leadership and membership levels does not manipulate the members but addresses real issues in the community.

Further, the COCZ needs to carefully consider how to address the issue of $\mathrm{CE}$, because the 'community of faith' is made out of diverse individuals from diverse cultures, societies and backgrounds. Oneness in Jesus Christ means that Christ has made from many parts one body with different functions important for the health and life of the whole body (1 Corinthians 12:12-31). The COCZ thus is ushered in the thinking of the best method of education that coheres people to a commonality of the church's transformation purpose. In this study, Frerian dialogical methods are appraised for use towards a common vision, goals and purpose for the future of the successful COCZ transformation. The leadership should take account of individuals who may feel their positions are threatened by the transformation and guarantee their future useful contribution by retaining some of the power they already exercise. If the church fails to do so, such people always find sympathisers across all divides of the church membership.

Secondly, the COCZ needs to consider the diversity of agendas. For one, dissenters (AM) had an option of remaining in the church, to shape how the church constitution could foster Christian unity rather than dividing the church. They promised that the church would be a safe and harmonious place, and they could profitably participate in the unfolding transformation in the church. Dissenters were genuinely afraid of losing control of the church to the marauding group of young and energetic, often intelligent, eloquent and educated pastors, most of whom had or were acquiring master's or doctoral degrees. At first, the dissenters felt with determination that the transformation project would fail because they felt pastors had little access to foreign and government funding, and at the time they were generally seen as poorly educated to meaningfully engineer a successful transformation. Moreover elders had the details of international links and legal documents of the church's properties in the country. After an NCC meeting on 24 September 2016, one elder positively claimed:

'When we saw pastoral enthusiasm with the COCZ transformation project, we felt that we, teachers, have the money; so we will wait and see what they, pastors, without salaries, will do in the church. We hoped they will, on account of resources, one day will surrender all responsibility back to us, the owners of the church, who knew everything for missionaries ordained us to own and to run the church.'

On the other hand, some pastors also had the same thinking, and Pastor Gangata of High Glen Church of Christ, Harare, after the summit on 24 February, 2017, at Windsor Park Church of Christ, Gweru, stated:

'We [pastors] felt that God called us to preach, teach, and live on benevolence as Jesus commanded. We felt that these university graduate pastors were soiling our church and diluting our ministerial duties. We felt the process was going to die a natural death, but we are surprised by the seriousness and efficiency [with which] the process has picked [up] momentum.'

The 'prophets of doom', so to speak, were shamed because most pastors engaged in income generating projects, paid professions like teaching and nursing, and others acquired higher degrees to become theologians and academics. For the most part, most pastors have surpassed the laity in education, and pastoral leadership has successively been becoming one of the most effective forms of leadership in the church because of their peculiar pastoral and professional touch on church programmes, projects and activities. In the past, lay leaders used to secretly borrow programmes and projects from other churches.

With these reflections, the COCZ needs to know that these differences exist even in the NEC and the NCC and that not everyone is totally committed to the TP or in support of church projects and programmes. The COCZ needs to accept that as long as certain personalities are in leadership positions in the NEC, some sections of the COCZ fraternity will forever oppose and criticise the leadership. This is a question of power and domination, where dissenters feel that they would rather control the goings-on in the NCC through their appointee(s) or else they will be out of the relationship. Paulo Freire also cautions us to re-examine ourselves if we get to the top, to ensure that as former oppressed we do not in turn adopt the former oppressor's oppressive tendencies once we, ourselves, attain the same power (Freire 1973:53). 
Further, in the kairos moment (time measured by events), the chronos (time measured by process or history) was ignored (Smith 1969:1-13):

Kairos is, therefore, peculiarly relevant to historical action and to historical enquiry because it points to the significance and purpose of events and to the idea of constellations of events yielding results which would not have been possible at other times and under other circumstances. (p. 2)

The postmillennial time was a kairos time for the COCZ to address the tasks at hand. However, it is necessary to understand the history and process, as '[k]airos presupposes Chronos and is therefore a necessary condition for history and historical knowledge' (Smith 1969:2). In fact the COCZ's transformation is a process that has needed both kairos and chronos time to journey together with local converts, former leaders and the marginalised groups. This could only have happened if the administrative and legal parameters, which the church put in place by accepting its first binding constitution on 19 September 2015, were implemented. The COCZ's transformation thus attended to the kairos moment because the context and existential realities demanded it. However, leaders do not need to neglect the chronos moment to keep the unity of the church. The church has a past to confront in journeying into the future, and this past has a history of contrasts and contradictions that demand engagement. This history has led to problems of MRCs (Masengwe et al. 2012), which demand that CE be a focal part of the life of the church. Thus, the COCZ today needs to theologically and spiritually reflect, through a wellmonitored, action-based education process that promises to implement results like the church's 2012 research commission on church structuring that was formally rejected by the former leadership of the church but informally became the formal process. ${ }^{1}$ Education makes the COCZ understand the nature of church it wants to become, and it may take several years before the fruits of education can be realised (Tyre 2000:123).

Further, the COCZ can be transformed by people with good facilitation skills, one where participants are involved and are dialogued with, rather than told what to do and what is going to happen: 'Because of the obsession with talking and the competitive nature of our humanness we find it difficult to listen and cooperate' (Storey 1994:12). A dialogical approach was used by the MCSA, reflected in Storey (1994), and it shows that in their past they used to come to meetings where they were fed information to carry back home where they were expected to dialogue with the congregants. With the introduction of the dialogical method, members improved their communication methods where learning at every level was done through dialogical discussions towards summarising, resolving and recommending the way forward. Musa Dube (2010:212) on dialogue in addressing HIV and AIDS described how ‘ $[a]$ particular concern of ... such reading

1.In 2012 , the pastors' fraternity asked the national leadership of the church to set up a church commission to review the church's leadership and operation structures. a church commission to review the church's leadership and operation structures. When the results were released in December 2012, the national leaders refused to implement them because they were viewed to be out of sync with the church's founding ideals. strategies should seek to provide liberation and healing for those struggling with this most pernicious of human scourges'. They began to listen to each other, and all members became cooperative and participative in the process. Empowering members can be frustrating to incompetent leaders, though, as members raise important questions, identify topical issues, discuss concerns undermining progress and propose practical and progressive options to the leadership. This is a problem of the success rather than the failure of education (Storey 1994:12).

This article appraises the importance of education in the life of the church, one which is liberating and empowering for both the dissenters and general members (Groome 1980:115). The COCZ needs to see that it uses appropriate CE methods to successfully transform its membership and eventually the church (Seymour 1997:34). The dialogical process justifies the ends of proper $\mathrm{CE}$, and thus the COCZ also needs to invest in training its church leaders in facilitation skills, for if they use poor teaching methodologies, there will never be any success in the church. Thus, the COCZ needs to invest money, people and time in training leaders on dialogical facilitation skills for all kinds of success in the church, where local church members end up being empowered, confident, enthusiastic and participative. On blaming the current scenario in the COCZ, Elder Shumba of Windsor Church of Christ, Gweru, in an interview on 25 February 2017 said:

'The COCZ is in a state in which it is because its leadership, both clergy and laity, are rowdy, unrefined and greedy individuals who believe that our church's answers come from American support. Some ministers who went to the USA use their privileges to curve [sic] an identity of the church they can use for perpetuation of their projects, and thus most of their advices are bending towards idolatry and paganism, leading to the divisions we have in the church today. Our church no longer requires to be led or guided by American educated pastors and elders because they use money as their only eloquence to rally people behind them not genuine love for the church.' (Interview, 25 February 2017)

Elder Shumba seems to be attuned to the transformation concerns in the COCZ for self-sustenance, self-financing and self-definition in the Zimbabwean context, which differs from those of America. This similar thinking was expressed through the Church Moratorium in Kenya. The COCZ is thus denying that it lacks in leadership capacity and potential to take the church to the next step. The COCZ seems to require grounded leadership on national issues, which appreciates social changes in the society and is not going to use the church to propel its financial and economic interests and ends. One pastor reminded the researcher of the foiled negotiation project with the dissenters. The CC and the CMP are transformational tools the COCZ has chosen to use; unfortunately, the COCZ did not prepare its clergy and the laity on how to negotiate it skilfully to manage interests in the change process. The COCZ has been made vigilant against dissenters' strategies of peddling their own candidates to starve the baby and eventually kill it. 
This article argues for the dialogical model of education for designing CE projects and describes how the NEC can use it to teach members during the current turbulence to birth an intact, stronger, healthy and growing COCZ among other churches from the RM family group in Zimbabwe. The COCZ has many advantages, but unfortunately it is too old, big and obese to deal with them without a change of attitude, leading to all kinds of problems; thus, a dialogical process is here hailed as an appropriate way to a healthy TP. When a church is undergoing change, it is expected that members will be the first to be changed before church structures are changed. This also took place during the most difficult years in the country, which no doubt borrowed from the socio-political challenges of the time (Chitando, Taringa \& Mapuranga 2014). For 'any church to deal with change and continuity, it needs Christian education' (Bruggermann 1982:5). Unfortunately, dissenters emphasised the pristine theologies of the church by referring to the RM ideals of the 19th century Second Great Awakening period, stating, '[ $w]$ ] want our faith as it was brought to us by the [white] missionaries' (Bungu 2014). It is with the dissenters that the change process in the COCZ has been at its most difficult, because the dissenters always change their positions on their opposition to and criticism of the process. One of the challenges in the leadership of the COCZ has been that it fathomed foreign-trained, and usually foreign-sponsored, leaders. This effectively treated locally trained pastors, even those with higher academic qualifications, as 'boys misleading the church'! This remark was privately made during the February 2015 preachers' summit by one of the dissenters in a preaching summit, referring to chairpersons of both the NEC and the pastors' fraternity. Thus, locally trained ministers without foreign supporters remained boys and infants in the faith, incapable of taking up church leadership positions. Pastors without foreign support were just as good as laypeople and thus were not supposed to be afforded the dignity of holding important leadership posts in the church. 'Boys' is a derogatory term that referred to African men, useless in the eyes of white colonisers. However, here it was used premised on the idea that pastors lacked technical, tactical, technological and theoretical skills. However, perpetuation of this attitude has proven to be detrimental to the COCZ's transformation as some ministers are acquiring higher degrees and furthering their ministerial formation.

Finally, the COCZ is challenged to consider theological reflection in the church. It is noteworthy to mention that a doctrine booklet was once developed by Christians at Mashoko Mission. While no one examined the material worthiness of the booklet at the time, it was a fair attempt to reproduce a doctrinal teaching book that was circulated but had few new reflections to excite the church. New changes have indicated that the COCZ had to invest in the transformative process of dialogical theological education to evaluate and address the members' questions. Of key importance has been the work of the Holy Spirit in the church of today. The church is challenged to examine the work of God through the Holy Spirit inside and outside the church, to allow for the wider work of the Holy Spirit in the world
(Bosch 1991:379, 489, 494. 150, 517). For this reason, an elderly pastor, Pastor Enock Jirrie, admitted:

'None of us ever thought of looking back at the successes and failures of our ministries to learn from each other. Instead, we continually justified our rightness against the wrongness of our followers forgetting that gakanje rinofamba nedivi kuteedzera mafambiro amai varo [a crab moves by its side in imitation of its mother - congregants follow the way their pastor lives]. One of the journey-stories with CC and CMP is that we are beginning to realise our challenges, but as well to ask how others have done it successfully. The CC and CMP is a precious experience in the history of the COCZ ... an anthology of our religious walk, together with the analysis and interpretation of our gifted academics, to help us to avoid repeating the same old stories we made in the past. If there is something that God did, [it] is that he has progressed and transformed his church, but we unfortunately did not collect, analyse and model God's involvement in the lifestories of our members. For some of us, to take forty years of ministry without time [for] reflection, discernment and constant dialogue to reach genuine transformation was a real loss.' (Interview, 19 September 2015)

With this confession, this study endeavours to make observations and draw a conclusion to the study.

\section{Conclusion}

The article has argued that for the COCZ to remain relevant to a transforming Zimbabwean society, it needs to undergo a process of renewal of its own, while its individual members do the same. The COCZ thus needs to revisit its RM ideals; from there to redress its traditional, religious, ethical and theological resources and to also revisit its systems, processes, products, paradigms and enterprises; and to evaluate its goals, mission, ministry and core business. As advanced by this article, the COCZ's core strategy is dialogical CE: to firstly transform its people and eventually the institution. Thus, it was not enough for the COCZ to engage in CC and the CMP, which focused on its systems and structures without firstly transforming its people and only then the doctrine and theology of the church. This transformation has to faithfully go down to the church's theological foundations, wherein the past informs the present and the future, if the church can be vibrant and relevant (Chitando 2013). The question this study has asked and tried to answer is:

What does it mean to be the COCZ in the fast-changing Zimbabwean society, and what process should the COCZ undergo to prepare it to play a meaningful role in the nation?

Finally, the study has considered a method of facilitating the COCZ transformation that encourages full membership participation and dialogical engagement. In this way, a full COCZ transformation can only take place if the process is accompanied with an intentional CE dialogical pedagogy strategy (Freire 1973). Areas warranting further research include whether the postmillennial transforming COCZ is gaining the skills and capacities to become a premier church of the postmillennial challenges of globalisation and technological advancement. 


\section{Acknowledgements Competing interests}

The authors declare that they have no financial or personal relationships which may have inappropriately influenced them in writing this article.

\section{Authors' contribution}

Both authors equally contributed to the writing and research of this article.

\section{References}

Adeyemo, T., 2006, (Download pdf), Africa Bible Commentary: A One-Volume Commentary, Written by 70 African Scholars, Zondervan, Zondervan.

Altman, D., 2014, 'The Church of Christ in Zimbabwe: The Missionary Dream', The Church of Christ in Zimbabwe (COCZ) National Conference, Gweru, Somabhula, August 21-24.

Bediako, K., 1992, Theology and identity: The impact of culture upon Christian though in the second century and in modern Africa, Paternoster Publishing, Cumbria, United Kingdom.

Bhebhe, M., 2016, 'Religio-culture, fear, and Zimbabwe's leadership perceptions', Perichoresis 14(1), 75-100. https://doi.org/10.1515/perc-2016-0005

Bless, C. \& Hugson-Smith, C., 1995, Social research methods: An African perspective, Juta, Lusaka.

Bosch, D.J., 1991, Transforming mission: Paradigm shifts in theology of mission, vol. 16, Orbis Books, New York:

Bruggermann, W., 1982, The creative God: The canon as education, Fortress Press, Philadelphia, PA

Bungu, Z., 2014, Comment by a member of the Constitutional Making Process (CMP) for the Church of Christ in Zimbabwe (COCZ) constitution, Mucheke Secondary School, Masvingo.

Carr, B. \& Kemmis, S., 1991, Action research, Deakin University, Victoria.

Chigwedere, A., 2002, Funeral speech at Grace Todd's funeral at Dadaya Church, TPPC, Zimbabwe, 13th January.

Chitando, E., 2013, “"Faithful men of a faithful God"? Masculinities in the Zimbabwe Assemblies of God Africa', Exchange 42(1), 34-50. https://doi. org/10.1163/1572543X-12341249

Chitando, E., Taringa, N.P. \& Mapuranga, T.P., 2014, 'Zimbabwean theology and religious studies during the crisis years (2000-2009): A preliminary study', Studia Historiae Ecclesiasticae 40(1), 173-189.

De Gruchy, J., 2005, The Church struggle in South Africa, David Phillip, Cape Town.

De Gruchy, S., 2003, 'Theological education and social development', Missionalia 31(3), 451-466.

Dombo, S., 2014, 'Refusing to be co-opted? Church organizations and reconciliation in Zimbabwe with special reference to the Christian Alliance of Zimbabwe 20052013', Journal for the Study of Religion 27(2), 137-171.

Dube, M., 2010, 'Go Tla Siama. O Tla Fola: Doing Biblical Studies in an HIV and AIDS context', BT-Equinox Publishing Ltd 8(2), 212-241.

Duncan, G.A., 2002, 'A place in the sun?: The role of the Church in moral renewal and social transformation', Verbum Et Ecclesia JRG 23(2), 333-342. https://doi. org/10.4102/ve.v23i2.1198

Freire, P., 1973, Education for critical consciousness, Continuum, New York.

Freire, P., 1976, Pedagogy of the oppressed, Penguin, London.

Freire, P., 1985, The politics of education, MacMillan, London.

Freire, P., 1986, Pedagogy of the oppressed, Penguin, London.

Freire, P. \& Shor, I., 1987, A pedagogy for liberation, MacMillan, London.

Groome, T., 1980, Introduction to Christian religious education, Harper and Row Publishers, San Francisco, CA.

Hart, R., 2016, “'Original Restoration Movement" and "Transformational Leadership", The Church of Christ in Zimbabwe (COCZ) National Conference, Gweru, Somabhula, 18-21st August.
Jirrie, E., 2011, Conference review meeting for the Church of Christ in Zimbabwe (COCZ) 2010 National Conference, verbal statement, February 2011, Masvingo.

Jirrie, E., 2015, Commentary by a member of the Constitutional Making Process (CMP) $P$ for the Church of Christ in Zimbabwe (COCZ) constitution, Somabhula, Gweru.

Machingura, F. \& Nyakuhwa, P., 2015, 'Sexism: A hermetical interrogation of Galatians $3: 28$ and women in the Church of Christ in Zimbabwe', Journal of Pan African Studies 8(2), 92-113.

Mafohla, S., 2017, Clergy-Laity relations: An investigation into power relations between the clergy and laity in the Church of Christ in Zimbabwe (COCZ), Midlands State University (MSU), Gweru.

Mafusire, J., 2015, Church of Christ in Zimbabwe: Report on the constitutiona adoption meeting on 19 September 2015, COCZ, Harare.

Magwidi, E., 2015, Presidential Speech at the Constitutional Referendum for the Church of Christ in Zimbabwe (COCZ), Somabhula, Gweru.

Maluleke, T.S., 1997, “"Review article”: In Search of the true character of African Christian Identity-A review of the theology of Kwame Bediako', Missionalia 25(2), 210-218.

Manyonganise, M., 2016, The church, national healing and reconciliation in Zimbabwe: A womanist perspective on Churches in Manicaland (CiM), PhD Thesis, University of Pretoria, Pretoria.

Masengwe, G., 2010, The church's role in social healing and reconciliation in Zimbabwe: Finding a deeper theology of reconciliation in the National Vision Discussion Document in Zimbabwe, Lambert Academic Publishers. Bramberg, Germany. ISBN 978-3-8383-6148-2

Masengwe, G., Machingura F. \& Magwidi, E., 2012, 'An excavation on Church governance: The question of autonomy in the light of the disempowered African Church converts in the Church of Christ in Zimbabwe (COCZ)', Journal of Research in Peace, Gender and Development 2(9), 185-194.

Mate, F., 2016, Statement uttered in the Collen-Brander Church of Christ (CCOC) meeting, Collen-Brander Church of Christ (CCOC), Bulawayo.

Matikiti, R., 2014, 'Violence in early Christian writings: Lessons for Christians in independent Zimbabwe', Studia Historiae Ecclesiasticae 40(2), 1-18.

Meylahn, J.-A. \& Musiyambiri, J., 2017, 'Ubuntu leadership in conversation with servant leadership in the Anglican Church: A case of Kunonga', HTS Teologiese Studies/Theological Studies 73(2), a4509. https://doi.org/10.4102/hts. v73i2.4509

Mwambazambi, K. \& Banza, A.K., 2014a, 'Developing transformational leadership for sub-Saharan Africa: Essential missiological considerations for church workers', Verbum et Ecclesia 35(1), Art. \#849, 9 pages. https://doi.org/10.4102/ve. v35i1.849

Mwambazambi, K. \& Banza, A.K., 2014b, 'Four-dimensional conversion for spiritual leadership development: A missiological approach for African churches', HTS Teologiese Studies/Theological Studies 70(3), Art. \#1953, 9 pages. https://doi. org/10.4102/hts. v70i3.1953

Oliver R., 1995, The Next Step: The continuing story of a church in a new land, Salty Print, Cape Town.

Palmer, P., 2001, Courage to teach, Jossey-Bass, San Francisco, CA.

Paul, S. \& Grundy, T., 2011, 'The Dadaya years: The challenge of understanding Garfield Todd', The Round Table 100(417), 629-638. https://doi.org/10.1080/003 58533.2011.633378

Rothman, L. \&Thomas, C., 1994, Intervention research design and development for human service, The Hathworth Press, New York.

Seymour, J., (ed.), 1997, An approach to Christian education, Abingdon, Nashville, TN.

Sibanda, T., 2016, An Investigation into the Significance of the Church of Christ in Zimbabwe's National Administrative Operational Structure (NAOS) from 2015-2018, ZCC - Ecumenical Resources Training Centre (ERTC), Harare.

Smith, J.E., 1969, 'Time, times, and the "Right Time": “Chronos" and "Kairos"', The Monist 53, 1-13.

Storey, P., 1994, Journey begun: The story of the church in the new land, Salty Print, Cape Town.

Theilen, U., 2002, Gender, race, power and religion: Women in the Methodist Church of Southern Africa in post apartheid society, Peter Lang, Metuchen, NJ.

Tyre, K., 2000, The basics of Christian education, Chalice Press, St. Louis, MO.

Villa-Vicencio, C., 1992, A Theology of reconstruction: Nation-building and human rights, Cambridge University Press, Cambridge.

Walshe, P., 1995, Prophetic Christianity and the liberation movement in South Africa, Cluster Publications, Pietermaritzburg.

Westerhoff, J., 1976, Will our children have faith?, The Winston Seadbury, Minnesota. 